\title{
Correction to: Arbovirus and seizures
}

Mingrui Zheng ${ }^{1}$, Shichuo Li ${ }^{2}$, R. Edward Hogan ${ }^{3 *}$ and Meihua Yang ${ }^{3,4^{*}}$

\section{Correction to: Acta Epileptologica (2020) 2:17 https://doi.org/10.1186/s42494-020-00026-w}

After publication of this article [1], it is noticed the article contains an error: the section below should be placed between the section headings of 'Pathogenesis' and 'Activated glia' on page 2 .

\section{Tropism with the brain}

JEV's neurotropism is a relevant factor of its pathogenesis. Neurotropism is not synonymous with neurovirulence, but they can be associated with each other in some cases. The JEV typically replicates before it spreads to local lymph nodes. Then the liver, heart, kidney and other organs the blood-brain barrier (Fig. 2). To cross the barrier, JEV replicates in endothelial cells inflammatory cells that carry the virus (Fig. 3).

The original article has been updated.

\section{Author details}

${ }^{1}$ West China School of Basic Medicine and Forensic Medicine, Sichuan

University, Chengdu 610041, China. ${ }^{2}$ China Association Against Epilepsy (CAAE), Beijing, China. ${ }^{3}$ Department of Neurology, Washington University, St. Louis, MO 63110-1093, USA. Epilepsy Centre, Department of Neurosurgery,

Xinqiao Hospital, Army Military Medical University, Chongqing 400037, China.

Published online: 17 November 2020

\section{Reference}

1. Zheng M, Li S, Hogan RE, et al. Arbovirus and seizures. Acta Epileptologica.

2020;2:17 https://doi.org/10.1186/s42494-020-00026-w.

The original article can be found online at https://doi.org/10.1186/s42494020-00026-w.

*Correspondence: hoganre@wustl.edu; ymh070916@163.com;

meihua.yang@bjc.org

${ }^{3}$ Department of Neurology, Washington University, St. Louis, MO 63110-1093,

USA

Full list of author information is available at the end of the article

(c) The Author(s). 2020 Open Access This article is licensed under a Creative Commons Attribution 4.0 International License, which permits use, sharing, adaptation, distribution and reproduction in any medium or format, as long as you give appropriate credit to the original author(s) and the source, provide a link to the Creative Commons licence, and indicate if changes were made. The images or other third party material in this article are included in the article's Creative Commons licence, unless indicated otherwise in a credit line to the material. If material is not included in the article's Creative Commons licence and your intended use is not permitted by statutory regulation or exceeds the permitted use, you will need to obtain permission directly from the copyright holder. To view a copy of this licence, visit http://creativecommons.org/licenses/by/4.0/. 